\title{
Different palm oil production systems for energy purposes and their greenhouse gas implications
}

\author{
Birka Wicke*, Veronika Dornburg, Martin Junginger, André Faaij
}

Department of Science, Technology and Society, Copernicus Institute for Sustainable Development and Innovation, Utrecht University, Heidelberglaan 2, 3584 CS Utrecht, The Netherlands

\section{A R T I C L E I N F O}

Article history:

Received 13 August 2007

Received in revised form

25 March 2008

Accepted 3 April 2008

Available online 21 May 2008

Keywords:

Biodiesel

Electricity

Greenhouse gas

Life cycle inventory

Palm fatty acid distillate

Palm oil

Sustainability criteria

\begin{abstract}
A B S T R A C T
This study analyses the greenhouse gas (GHG) emissions of crude palm oil (CPO) and palm fatty acid distillate (PFAD) production in northern Borneo (Malaysia), their transport to the Netherlands and their co-firing with natural gas for electricity production. In the case of $\mathrm{CPO}$, conversion to biodiesel and the associated GHG emissions are also studied. This study follows the methodology suggested by the Dutch Commission on Sustainable Biomass (Cramer Commission). The results demonstrate that land use change is the most decisive factor in overall GHG emissions and that palm oil energy chains based on land that was previously natural rainforest or peatland have such large emissions that they cannot meet the $50-70 \%$ GHG emission reduction target set by the Cramer Commission. However, if CPO production takes place on degraded land, management of CPO production is improved, or if the by-product PFAD is used for electricity production, the emission reduction criteria can be met, and palm-oil-based electricity can be considered sustainable from a GHG emission point of view. Even though the biodiesel base case on logged-over forest meets the Cramer Commission's emission reduction target for biofuels of $30 \%$, other cases, such as oil palm plantations on degraded land and improved management, can achieve emissions reductions of more than $150 \%$, turning oil palm plantations into carbon sinks. In order for bioenergy to be sustainably produced from palm oil and its derivatives, degraded land should be used for palm oil production and management should be improved.
\end{abstract}

(c) 2008 Elsevier Ltd. All rights reserved.

\section{Introduction}

Over the past decade, many industrialised countries have sharply increased the amount of biomass they import. This is primarily due to the fact that such countries introduced policies to stimulate renewable energy use and that imported biomass is often more cost-efficient than domestic biomass. Increasing global trade and consumption of bioenergy has been accompanied by a growing concern about the environmental, ecological, and social impacts of bioenergy production. This concern has been spurred by reports about bioenergy crop production causing deforestation and the associated loss of biodiversity, greenhouse gas (GHG) emissions, displacement of forest people and related land conflicts, to name just a few. Southeast Asian palm oil, in particular, has been associated with major problems such as clear-cutting of natural rainforest, destruction of ecologically valuable peatland and instigation of social conflicts, and its sustainability has been intensely debated in many countries [1-4]. As a result of these unintended and undesired effects of bioenergy production, various initiatives have attempted to develop sustainability criteria in order to ensure sustainable bioenergy trade [5-9]. In Europe, such efforts began in Belgium where an energy company developed its own

*Corresponding author. Tel.: +3130253 4299; fax: +31302537601.

E-mail address: b.wicke@uu.nl (B. Wicke).

0961-9534/\$-see front matter ( $) 2008$ Elsevier Ltd. All rights reserved.

doi:10.1016/j.biombioe.2008.04.001 
certification system that is widely accepted by Belgian authorities [5,6]; in the UK where, as part of the renewable transport fuel obligation, reporting guidelines on carbon and sustainability are being developed [7]; and in the Netherlands where the so-called Cramer Commission on sustainable production of biomass has recently finished its work [8]. The European Commission is also working on legislation to guarantee the sustainable production of biomass [9].

In all of these initiatives, the GHG balance is an important sustainability criterion because the presumed GHG emission savings compared to fossil energy are a key driver of increasing bioenergy consumption. However, it cannot simply be assumed that bioenergy results in GHG emission savings since both the land use change (LUC) associated with biomass production and inputs needed for such LUC like fossil fuels for machinery, fertiliser, and pesticides can generate GHG emissions $[10,11]$. LUC in particular has been found to strongly affect the GHG balance either by emissions from, for example, the net loss of standing biomass when natural rainforest is converted to other uses, or by sequestration of carbon from, for example, a net increase of soil carbon when degraded land is converted to bioenergy production [11-14].

Although methods for calculating GHG balances have been developed for the Belgian, British, and Dutch initiatives $[5,15,16]$, several aspects of implementation and verification of this sustainability criterion remain debatable. Such unsettled aspects include the method of allocating emissions to by-products, the allocation period over which LUC emissions should be amortised and the choice of the fossil electricity reference system. Moreover, these methodologies have not yet been tested on specific production cases. Therefore, the main objectives of this study are (1) to analyse the GHG balance of specific palm-oil-based energy chains and (2) to study the effects on the GHG balance of the three abovementioned unresolved methodological issues, as well as the effects of different reference land use systems and of different management options. In order to do so, the following chains are considered:

(1) CPO electricity chain: production of crude palm oil (CPO) in northern Borneo, Malaysia, transport to the Netherlands and co-firing at a natural gas power plant in the Netherlands;

(2) PFAD electricity chain: production of the palm oil derivative palm fatty acid distillate (PFAD) in northern Borneo, Malaysia, transport to the Netherlands and co-firing with natural gas for electricity production in the Netherlands; and

(3) Biodiesel chain: using the CPO for the production of biodiesel in Malaysia and transporting the biodiesel to the Netherlands for use in vehicles [17].

The GHG emission calculations are based on the methodology developed by the Cramer Commission since, in order for the analysed chains to be considered sustainable, they will have to meet the Commission's criteria.

The remainder of the study is organised as follows: The methodology applied for calculating the GHG emission reductions of bioenergy compared to fossil reference systems is described (Section 2), and the data input is presented (Section 3). Then, the results of the GHG analysis of the three chains, of their various cases and of the effects of the methodological choices are presented in Section 4, followed by a discussion of the results and the methodological choices (Section 5). Section 6 presents the study's final conclusions.

\section{Methodology}

This study determines the GHG emissions from CPO and PFAD-based electricity and CPO-based biodiesel production according to the Dutch Cramer Commission methodology for GHG calculations [16], which is based on a life cycle inventory and accounts for all GHG emissions that arise between initial land use conversion through final use of the palm-oil-based energy.

The three most important GHGs, carbon dioxide $\left(\mathrm{CO}_{2}\right)$, methane $\left(\mathrm{CH}_{4}\right)$, and nitrous oxide $\left(\mathrm{N}_{2} \mathrm{O}\right)$, are included. For comparing the emissions of these three gases, the concept of global warming potential (GWP) is applied following the guidelines of IPCC, allowing for a comparison of the radiative forcing of the different gases [18]. The other main GHGs (hydrofluorocarbons, perfluorocarbons, and sulphur hexafluoride) are not taken into account as they are insignificant in the bioenergy production chains.

The GHG emissions of by-products, which are used outside the system boundaries, are calculated on the basis of system extension. This approach assumes that the by-product generated can replace the same or a similar product that was produced from another feedstock. Due to this replacement, an emission credit for the avoided GHG emission from the original production of the product can be assigned.

The percentage of GHG emission reduction is calculated by dividing the difference in GHG emissions from the fossil and bioenergy chain by the emissions of the fossil reference system. The reduction percentage is measured against the standards set by the Cramer Commission, which requires an emission reduction of $50-70 \%$ for bioelectricity and $30 \%$ biodiesel in order for these to be considered sustainable [8]. A negative percentage of emission reduction refers to a bioenergy system that has larger emissions than the fossil energy system. A positive percentage of emission reduction refers to a bioenergy system that reduces GHG emissions compared to the fossil reference system. A percentage of emission reduction of more than $100 \%$ refers to a bioenergy system that sequesters more $\mathrm{CO}_{2}$ than is emitted in terms of $\mathrm{CO}_{2}$ equivalent throughout the production chain. The functional units are defined as production of $1 \mathrm{kWh}$ of electricity for the electricity chains and $1 \mathrm{MJ}$ fuel for biodiesel.

In addition to the percentage of GHG emission reduction, the emissions from palm oil energy chains are also expressed in terms of carbon payback time. This is the period of time that the bioenergy feedstock needs to be grown before the LUC emissions have been offset [19]. The carbon payback period is determined by dividing the net carbon loss from LUC per hectare by the amount of carbon saved per hectare and per year by the use of bioenergy (excluding LUC emissions).

For this study, case-specific data from a field visit of two plantations, two mills and one refinery in the Sandakan 
region of northern Borneo, Malaysia are used. The field visit was conducted in connection with a Roundtable for Sustainable Palm Oil and Cramer Commission pre-audit by the certification body Control Union in February 2007. The plantations visited were well managed, demonstrated by their integrated pest management, waste minimisation and landfill practices, zero burning, and habitat conservation and restoration. Each plantation had its own mill on site, but the refinery was located in Sandakan, approximately $100 \mathrm{~km}$ from the plantations, from where $\mathrm{CPO}$ and its derivative products can be directly shipped abroad. The GHG emissions of the transesterification process are based on data from the literature because the case study did not include transesterification of CPO.

\subsection{CPO electricity chain}

The first step in the CPO electricity chain is the land use conversion necessary to establish an oil palm plantation, followed by the production of the fresh fruit bunches (FFBs), the milling and production of $\mathrm{CPO}$, transportation of the CPO to the Netherlands, and CPO-based electricity production (Fig. 1). Each of these steps and the resulting GHG emissions and credits are described in more detail in the following sections.

\subsubsection{Land use change}

LUC refers to the conversion of one type of land to another (e.g. forestland to oil palm plantation). Such a conversion affects the carbon stocks of standing biomass, belowground biomass, soil carbon, and carbon stored in dead organic matter (DOM). Various reference land use systems are studied: logged-over forest (also referred to as "base case" because it resembles the case study), natural rainforest, peatland, and degraded land. The LUC emissions from aboveground biomass (AGB), DOM, and soil carbon stock changes are determined for each of the land use systems based on the Tier 1 methodology of the IPCC guidelines on GHG emissions from LUC [18].

The $\mathrm{CO}_{2}$ assimilation at the oil palm plantation accounts for only the $\mathrm{CO}_{2}$ that is fixed in the oil palm trunk and in the fronds that are not cut at harvest. This delineation is necessary so that it can be assumed that FFB and its products (CPO) and the by-products empty fruit bunches (EFB), palm kernel shells (PKS), and fibre are carbon neutral in the later steps of the production chain. FFBs and the fronds that are cut off at harvest are applied as organic fertiliser and dealt with in the following section.

For each unit of palm oil energy to account for its share of the GHG emissions from LUC and the assimilation of $\mathrm{CO}_{2}$ by the oil palms, the net emissions from LUC are

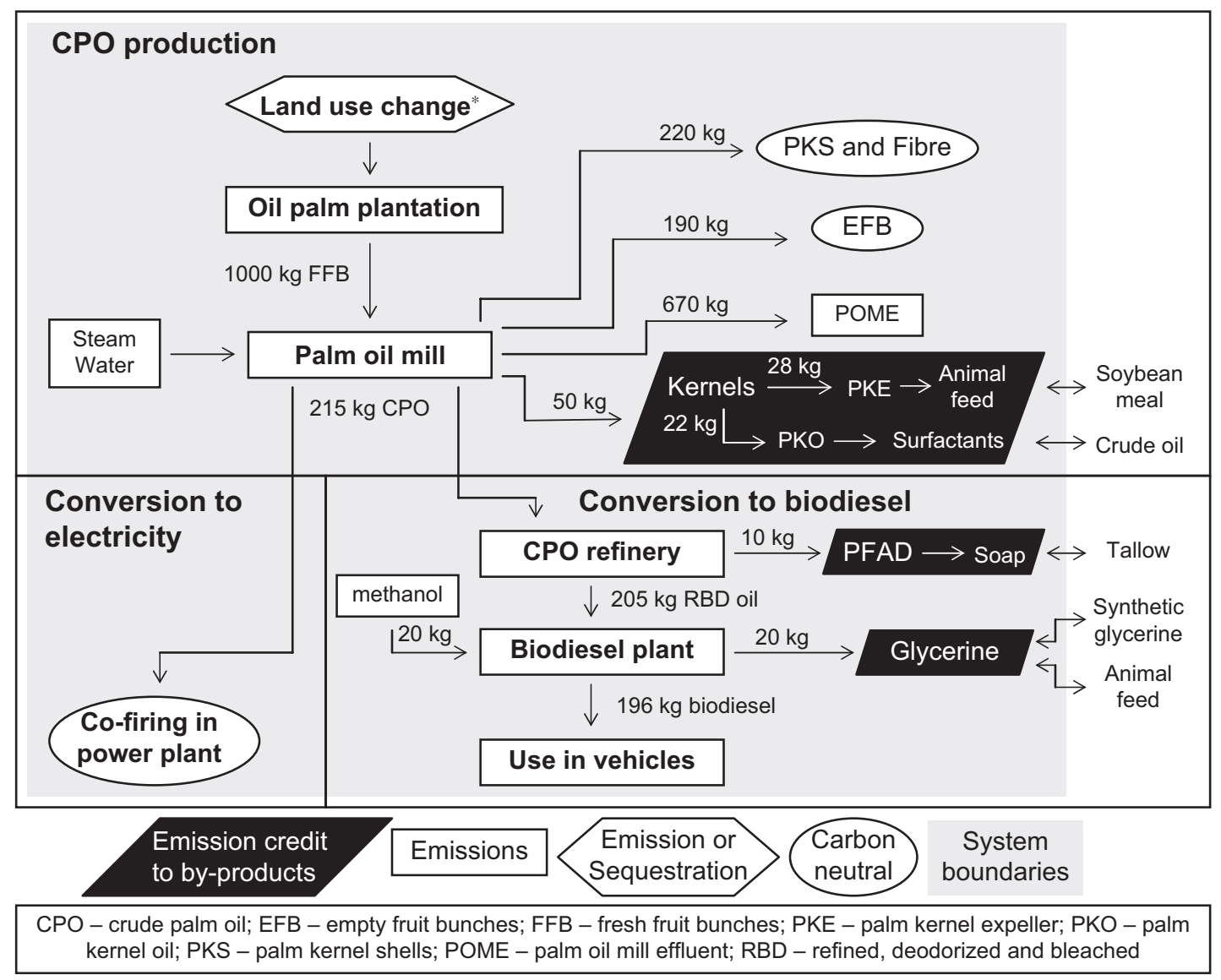

Fig. 1 - System boundaries of the two CPO-based chains with approximate mass flows and an overview of emission sources and credits. Not shown are the different transport stages that also cause GHG emissions. ${ }^{*}$ Whether $\mathrm{CO}_{2}$ is emitted or sequestered as a result of LUC depends on the land use reference system. 
calculated by

LUC emissions $=3.7 \times\left[\left(\right.\right.$ LUC C $/\left(T_{\text {LUC }} \times Y\right)$

$$
\left.-C_{\text {uptake }} /\left(T_{\text {plant }} \times Y\right)\right]
$$

where LUC emissions are the net emissions from LUC $\left(\mathrm{gCO}_{2}\right.$ eq $\mathrm{MJ}_{\mathrm{CPO}}^{-1}$ ); 3.7 the molecular weight ratio of $\mathrm{CO}_{2}$ to $\mathrm{C}$ (unitless); LUC C the loss of carbon (C) from LUC $\left(\mathrm{Cha}^{-1}\right)$; $\mathrm{C}_{\text {uptake }}$ the carbon uptake by oil palms during plantation lifetime $\left(\mathrm{C} \mathrm{ha} \mathrm{C}^{-1}\right) ; \mathrm{T}_{\mathrm{LUC}}$ the allocation time period of LUC emissions (yr); $\mathrm{T}_{\text {plant }}$ the plantation lifetime (yr); and $\mathrm{Y}$ the energy yield $\left(\mathrm{MJ}_{\mathrm{CPO}} \mathrm{ha}^{-1} \mathrm{yr}^{-1}\right)$.

For the situation in which peatland is drained and then planted with oil palm, the additional $\mathrm{CO}_{2}$ and $\mathrm{N}_{2} \mathrm{O}$ emissions from peat decomposition after drainage are determined according to the IPCC guidelines for LUC [18].

The displacement of prior crop production and the possible land use induced by the movement of prior crop production to other areas (indirect LUC) is not included in this study. However, this displacement may contribute significantly to the overall GHG emissions [20].

\subsubsection{Oil palm plantation}

Various GHG-emitting inputs (e.g. diesel and fertiliser) are needed for the production of FFB at an oil palm plantation. While most of the harvest is done manually, some machinery, farm equipment, and trucks for FFB transport require fossil energy and emit GHG. The GHG emissions from fossil energy are calculated by multiplying the amount of fuel needed per hectare of land by the emission factor of the fuel.

GHG emissions from the production of machinery and equipment, construction of buildings, and production and use of pesticides are disregarded as they are minor compared to overall emissions in the system [16].

Nitrogen (N) fertiliser applied at the oil palm plantations causes GHG emissions during its production and $\mathrm{N}_{2} \mathrm{O}$ emissions from its application to the field. Only the GHG emissions from $\mathrm{N}$ fertiliser production are calculated here because the emissions from phosphate and potash fertiliser production were found to be much smaller than $\mathrm{N}$ fertiliser production [16]. The GHG emissions from $N$ fertiliser production are calculated by multiplying the amount of a specific $\mathrm{N}$ fertiliser by the emission factor for producing that fertiliser.

The direct and indirect $\mathrm{N}_{2} \mathrm{O}$ emissions from organic and inorganic $\mathrm{N}$ fertiliser application are calculated according to the IPCC guidelines for $\mathrm{N}_{2} \mathrm{O}$ emissions from managed soils [18]. Since the organic fertilisers (EFB and fronds) are piled in thin layers on the ground, it can be assumed that they decompose aerobically and result in no additional GHG emissions.

The various GHG emissions from the plantation are then summed and converted to per unit of energy $\left(\mathrm{MJ}_{\mathrm{CPO}}\right)$ by dividing the emissions by the FFB yield, the oil extraction rate (OER) and the energy content of CPO.

\subsubsection{GHG emission flows at mill}

At the mill, GHG emissions arise from fossil fuel use (calculated as determined in the previous section) and from the palm oil mill effluent (POME), while emission credits are given to by-products. For the latter, GHG emission credits for by-products are only given if the by-product is used to replace another product outside the system boundaries, as is the case for kernels (Fig. 1). Kernels receive GHG emission credits because they are used to produce palm kernel oil (PKO), which can then be used for surfactant production, and palm kernel expeller (PKE), which is used as animal feed and is assumed to replace soy meal. It is assumed that PKO is a feedstock in the surfactant production of alcohol ethoxylates (AE) and that, as a final product, it replaces 3-mole $\mathrm{AE}$ from petrochemical feedstocks. A petrochemical-surfactant-by-PKO-surfactant displacement of 1:1 is assumed based on information given by Stalmans et al. [21]. Credit for PKO surfactant is calculated by first determining the emission factors of crude oil surfactants and PKO surfactants. The difference in emission factors is then multiplied by the amount of surfactants that can be replaced by PKO. The second by-product, PKE, is assumed to replace soybean meal as animal feed. The GHG emission credit for PKE is calculated by multiplying the difference in emission factor of soybean meal and PKE.

At the case study site, POME, i.e. the wastewater generated from clarification and other processing steps, is treated in open ponds in order to reduce its biological oxygen demand. During the anaerobic treatment, biogas with a composition of approximately $60 \% \mathrm{CO}_{2}$ and $40 \% \mathrm{CH}_{4}$ is generated [22]. The amount of carbon released as $\mathrm{CO}_{2}$ and $\mathrm{CH}_{4}$ is the same amount of carbon that had been sequestered during the growth of the FFB. Thus, the $\mathrm{CO}_{2}$ from biogas is considered carbon neutral. In contrast, $\mathrm{CH}_{4}$ from biogas has a higher GWP than the $\mathrm{CO}_{2}$ that was initially taken up and therefore cannot be considered neutral in terms of GHG emissions. To account for the initial $\mathrm{CO}_{2}$ uptake, the emission factor of $\mathrm{CH}_{4}$ from POME treatment is taken to be the GWP of $\mathrm{CH}_{4}$ $\left(23 \mathrm{tCO}_{2}\right.$-eq $\left.\mathrm{t}^{-1} \mathrm{CH}_{4}\right)$ minus the amount of $\mathrm{CO}_{2}$ that was taken up by the oil palm but then released as $\mathrm{CH}_{4}$ during POME treatment, i.e. $2.75 \mathrm{tCO}_{2} \mathrm{t}^{-1} \mathrm{CH}_{4}$. The GHG emissions from POME treatment are then calculated by multiplying this emission factor with the amount of $\mathrm{CH}_{4}$ produced.

\subsubsection{GHG emissions from CPO transport}

GHG emissions from transport encompass the transport of CPO by trucks to the harbour, by ocean vessel to Rotterdam, the Netherlands, and by inland ship from Rotterdam to the Claus Power Plant (Maasbracht, the Netherlands). GHG emissions from transporting CPO are calculated by multiplying the emission factor by the distance for each transportation step, adding up those emissions and then dividing by the energy content of CPO.

\subsubsection{GHG emissions from co-firing CPO}

The Claus Power Plant, operated by Essent, uses a natural gas boiler and a conventional steam cycle, which allows co-firing of vegetable oils without major modifications to the system. Built in 1977, the Claus Power Plant has a low electrical efficiency compared to modern combined cycle natural gas power plants. The $\mathrm{CO}_{2}$ emissions from co-firing $\mathrm{CPO}$ for electricity production are not accounted for in the GHG balance of CPO-based electricity as the $\mathrm{CO}_{2}$ emitted is equal to the amount that had been taken up in producing the FFB.

\subsubsection{Overview of $\mathrm{CPO}$ production cases}

All emissions from the CPO electricity chain are converted to emissions per $\mathrm{kWh}$ by applying the electric efficiency of the 
Claus Power Plant. CPO production is studied using various land use reference systems, methodological issues such as the allocation of land use emission over different time spans and different methods for allocating emissions to products and by-products, and management improvement options for the plantation and mill (Table 1). In each of the land use cases (cases 1-4), a different pre-conversion reference land use system is studied. In the management case (case 5), four management improvement options are studied in order to determine by how much the GHG emissions of the base case can be reduced. These options are:

1. Establishing new oil palm plantations on degraded land.

2. Reducing $\mathrm{CH}_{4}$ emissions from POME: anaerobic digestion of POME takes place in a closed system so that the generated biogas can be collected more easily. In this case, $\mathrm{CH}_{4}$ emissions from outdoor POME treatment and additional GHG emissions from replaced electricity production are avoided because the collected $\mathrm{CH}_{4}$ can be burned for producing electricity. If the national electricity grid is close to the mill, surplus electricity could be fed into the grid, replacing electricity from other sources.

3. Increasing the oil yield by planting better tree varieties, improving harvesting techniques (e.g. timing and collection), and better management.

4. Applying more organic $\mathrm{N}$ fertiliser such as the nutrientrich slurry from POME treatment.
In order to determine the effects of the different methodological choices, cases 6 and 7 account for different time periods over which the GHG emissions from LUC can be distributed. Cases 8-10 analyse the effects of different methods for allocating emissions.

\subsection{PFAD electricity chain}

CPO refining results in refined, bleached, and deodorised (RBD) oil as the main product or in its derivatives RBD stearin and olein. The only by-product of refining is PFAD, which results from filtering the fatty acids and amounts to less than $5 \%$ by weight of all processed CPO. PFAD is commonly used in producing soap, animal feed, plastics and other intermediate products for the oleochemical industry [23]. Additionally, its high energy content and the small modification that is needed to co-fire PFAD with natural gas or oil have contributed to its increasing use in power generation [24]. Fig. 2 illustrates the PFAD production chain, the various sources of GHG emissions and emission allocation to the RBD oil.

Although PFAD is considered a by-product, it is an important input for the oleochemical and animal feed industries. Therefore, this study includes the refining process in the PFAD production chain despite a differing suggestion from the Cramer Commission methodology [16]. Economic allocation of the GHG emissions from the refinery to PFAD

Table 1 - Description of CPO production cases

\begin{tabular}{|c|c|c|c|c|c|}
\hline $\begin{array}{l}\text { Chain } \\
\#\end{array}$ & $\begin{array}{l}\text { Name of } \\
\text { case }\end{array}$ & $\begin{array}{l}\text { LUC: original } \\
\text { land type }\end{array}$ & $\begin{array}{l}\text { LUC emission: } \\
\text { allocation period } \\
\text { (years) }\end{array}$ & $\begin{array}{l}\text { Allocation/ } \\
\text { system } \\
\text { extension }\end{array}$ & CPO/PFAD production data \\
\hline \multicolumn{6}{|c|}{ Land use } \\
\hline 1 & $\begin{array}{l}\text { Base case } \\
\text { (logged-over } \\
\text { forest) }\end{array}$ & $\begin{array}{l}\text { Logged-over } \\
\text { rainforest }\end{array}$ & $25^{\mathrm{a}}$ & $\begin{array}{l}\text { System } \\
\text { extension }\end{array}$ & Production data from case study \\
\hline 2 & $\begin{array}{l}\text { Natural rain- } \\
\text { forest }\end{array}$ & $\begin{array}{c}\text { Natural } \\
\text { rainforest }\end{array}$ & $25^{\mathrm{a}}$ & $\begin{array}{l}\text { System } \\
\text { extension }\end{array}$ & Production data from case study \\
\hline 3 & Degraded & $\begin{array}{l}\text { Degraded land } \\
\text { (grassland) }\end{array}$ & $25^{\mathrm{a}}$ & $\begin{array}{l}\text { System } \\
\text { extension }\end{array}$ & Production data from case study \\
\hline 4 & Peatland & $\begin{array}{l}\text { Peatland-forest } \\
\text { cover }\end{array}$ & $25^{\mathrm{a}}$ & $\begin{array}{l}\text { System } \\
\text { extension }\end{array}$ & Production data from case study \\
\hline \multicolumn{6}{|c|}{ Management } \\
\hline 5 & $\begin{array}{l}\text { Management } \\
\text { improvement }\end{array}$ & $\begin{array}{l}\text { Degraded land } \\
\text { (grassland) }\end{array}$ & $25^{\mathrm{a}}$ & $\begin{array}{l}\text { System } \\
\text { extension }\end{array}$ & $\begin{array}{l}\mathrm{CH}_{4} \text { collection and electricity production, } \\
\text { improved yields, increased organic fertiliser }\end{array}$ \\
\hline \multicolumn{6}{|l|}{ Method } \\
\hline 6 & 13 years & $\begin{array}{l}\text { Logged-over } \\
\text { forest }\end{array}$ & 13 & $\begin{array}{l}\text { System } \\
\text { extension }\end{array}$ & Production data from case study \\
\hline 7 & 100 years & $\begin{array}{l}\text { Logged-over } \\
\text { forest }\end{array}$ & 100 & $\begin{array}{l}\text { System } \\
\text { extension }\end{array}$ & Production data from case study \\
\hline 8 & Economic & $\begin{array}{l}\text { Logged-over } \\
\text { forest }\end{array}$ & 25 & $\begin{array}{l}\text { Allocation by } \\
\text { market price }\end{array}$ & Production data from case study \\
\hline 9 & Mass & $\begin{array}{l}\text { Logged-over } \\
\text { forest }\end{array}$ & 25 & $\begin{array}{c}\text { Allocation by } \\
\text { mass }\end{array}$ & Production data from case study \\
\hline 10 & Energy & $\begin{array}{l}\text { Logged-over } \\
\text { forest }\end{array}$ & 25 & $\begin{array}{c}\text { Allocation by } \\
\text { energy }\end{array}$ & Production data from case study \\
\hline
\end{tabular}

${ }^{a}$ While the average lifetime of a plantation is 25 years, the productive lifetime is only 21-23 years because no fruits are produced in the first years. The unproductive years are accounted for by averaging the FFB yield over the plantation lifetime. 


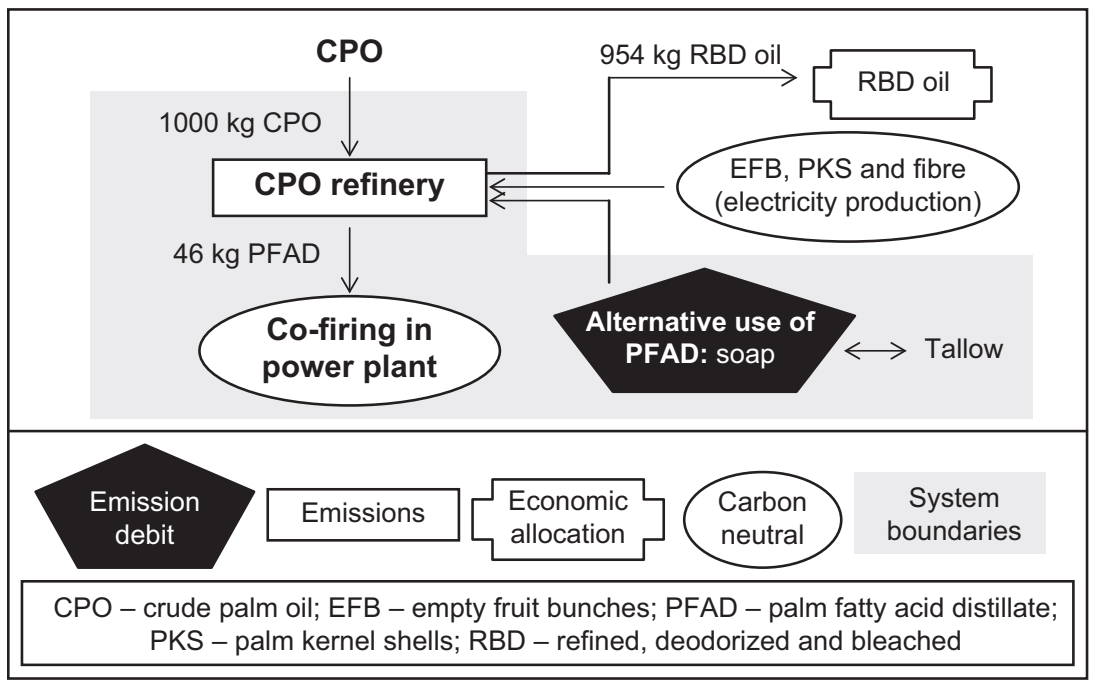

Fig. 2 - System boundaries of the PFAD electricity chain with approximate mass flows and an overview of emission sources/ credits. Not shown are the different transport stages which also cause GHG emissions.

and RBD oil is applied because RBD oil is the main product and is not further used in the chain.

Refining of CPO consumes steam and electricity, and in the case study electricity is obtained from three sources: purchased from the grid (emissions equal the amount of electricity bought multiplied by the emission factor of average Malaysian electricity production); produced onsite from biomass, i.e. from combustion of EFB, PKS and fibre from independent mills (the biomass streams for steam and electricity production are carbon neutral because the emitted carbon is assumed to equal the amount sequestered by EFB, PKS and fibre during their growth); and produced onsite from fossil diesel in a generator (emissions equal the amount of fossil diesel multiplied by the emission factor of fossil diesel). Other inputs required in the refinery are bleaching earth and phosphoric acid, but both in such small quantities $(7 \mathrm{~kg}$ bleaching earth $\mathrm{t}^{-1} \mathrm{CPO}$ and $500 \mathrm{~kg}$ phosphoric acid $\left.\mathrm{kt}^{-1} \mathrm{CPO}\right)$ that the possible emissions of their production and use can be neglected.

Since PFAD is currently primarily used in soap and detergent production, this study assumes that this is the alternative use of PFAD. It is further assumed that the PFAD for soap production is substituted by tallow from beef production as both contain mainly long chain esters and that this substitution takes place at a rate of 1:1 (by weight). Because PFAD consists of the same fatty acids as CPO, it is assumed that the 1:1 tallow to palm oil substitution ratio as applied by Postlethwaite [25] is also valid for PFAD to tallow. The GHG emissions of the alternative PFAD use are then calculated by first multiplying the amount of tallow by the emission factor of tallow and then dividing the result by the energy content of PFAD.

PFAD is transported in the same manner as CPO, and due to similar energy content and density values of PFAD and CPO, it is assumed that the fossil energy requirements (and therefore GHG emissions) for PFAD transport to and within the Netherlands is the same as for CPO (see Section 2.1.4). $\mathrm{CO}_{2}$ emissions from co-firing PFAD for electricity production are not accounted for as it is assumed that CPO is produced sustainably and thus the $\mathrm{CO}_{2}$ emitted in combustion equals the $\mathrm{CO}_{2}$ assimilated during plant growth.

\subsubsection{Overview of PFAD production cases}

In addition to the PFAD base case (economic allocation, case 1) described above, three deviations are also considered. In cases 2 and 3, the emissions of the refinery are allocated on the basis of mass and energy, respectively. The case "PFAD no refinery emissions" (case 4) is based on the notion that PFAD can be treated as a residue rather than a valuable by-product. In that case only the emissions associated with PFAD treatment, transport or consumption need to be accounted for. Emissions from fossil energy consumption during refining are excluded in this case.

\subsection{Biodiesel chain}

An alternative to using $\mathrm{CPO}$ in electricity production is its use in the production of biodiesel. In the main process, base catalyst transesterification, the triglycerides of the oil are reacted with methanol to form methyl ester and glycerine. The biodiesel chain is composed of CPO production, CPO refining, transesterification of RBD palm oil and transport and storage at the various stages (Fig. 1). It is assumed that CPO is first refined and the resulting RBD palm oil is used in the transesterification process because the filtering out of free fatty acids increases the oil-to-PME conversion efficiency [26].

The GHG emissions of CPO production and transportation to the refinery/harbour are taken directly from the calculations described in Section 2.1, and the emissions of CPO refining are based on the description of CPO refining in the PFAD chain in Section 2.2. Since PFAD is not further used in the biodiesel chain, an emission credit is given. PFAD is assumed to replace tallow in soap production at a substitution ratio of $1: 1$. The emission credit is calculated by multiplying the emission factor of tallow with the amount of tallow that can be replaced by the production of $1 \mathrm{MJ}$ of biodiesel.

RBD palm oil is transesterified at the refinery with the help of the catalyst sodium hydroxide $(\mathrm{NaOH})$ and methanol. 
The GHG emissions of transesterification are from the use of fossil energy and the production and use of fossil methanol and the catalyst; an emission credit results from the byproduct glycerine, which is assumed to replace synthetically produced glycerine.

The GHG emissions of biodiesel transport to the Netherlands are taken directly from the calculations described in Section 2.1, and literature findings are used to determine the GHG emissions from biodiesel distribution within the Netherlands. While the use of biodiesel in vehicles is generally considered carbon neutral, the carbon atoms from fossil methanol still contribute to atmospheric emissions. The amount of these emissions is determined by assuming that one carbon atom in the empirical formula of PME $\left(\mathrm{C}_{18} \mathrm{H}_{35} \mathrm{O}_{2}\right)$ has its origin in fossil methanol $[27,28]$.

The different CPO production systems and their effect on the GHG balance are also studied for the biodiesel chain. Here, only the variations in land use types and the management improvement cases are studied (cases 1-5). An additional case assumes that glycerine replaces wheat as animal feed rather than synthetically produced glycerine. This case is studied because replacing just five percent of fossil diesel with biodiesel in Europe would result in a glycerine production 30 times the size of current synthetic glycerine production in the EU [28]. Such an oversupply would cause the collapse of the glycerine market price-a development that is already being seen [29]. When the price for synthetic glycerine decreases, other uses of glycerine, such as animal feed, become more economically interesting [28]. While glycerine will only be used in animal feed if it is cheaper than alternatives, these two options of glycerine uses can be seen as the upper and lower limit of emission credits given and that, when new uses of glycerine are found over time, the emission credit is likely to be within these limits [28].

\subsection{Fossil reference system}

In order to determine the GHG emission reductions of the different bioenergy chains, a fossil reference system is defined, its life cycle emissions determined and the emissions compared to those of the bioenergy chains. In order to study the effect of how different reference systems may affect the emission reduction and whether meeting the reduction targets is affected by the choice of reference system, several reference systems are chosen for the electricity chains: Claus Power Plant (natural gas only), average Dutch electricity, a modern natural gas power plant, a coal power plant and average EU 25 electricity. In the case of diesel, the fossil reference system is fossil diesel from European production.

\section{Input data}

\subsection{CPO electricity production}

Data input to LUC emission calculations is based on the IPCC default values for different reference land use systems [18], except for the logged-over forest case where it is assumed that only $50 \%$ of the original biomass is left and that DOM carbon stock and soil carbon are similarly affected (Table 2).
The total amount of carbon assimilated at the plantation is based on the results of field experiments in Indonesia and is $95 \mathrm{tC} \mathrm{ha}^{-1}$ [30].

The FFB yield at the case study plantations was $31 \mathrm{t}$ FFB per hectare in 2006. This value is high compared to the national average yield, likely due to the fact that the plantations are currently at peak production. The case study yield is not applied in this study because it does not account for the first years in which the plantation was unproductive nor for yield changes over time. Instead an average FFB yield of $25 \mathrm{tFFBha} \mathrm{Hr}^{-1} \mathrm{yr}^{-1}$ over the lifetime of the plantation is assumed. The OER is $21.5 \%$ in the case study, a value also higher than the national averages, reflecting the good harvesting practices and management at the plantation. The energy content of CPO is assumed to be $36 \mathrm{MJ} \mathrm{kg}^{-1}$ [31].

The amount of fossil energy required at the plantation and the mill is taken from the case study and was found to be lower than data found in the literature [32]. The emission factors of the different fossil fuels are taken from the IPCC guidelines [18].

The amount of $\mathrm{N}$ fertiliser applied was determined at the case study plantation and is presented in Table 3. Although urea is drawn from several countries and ammonium sulphate from Japan, it is assumed that the emission factor from the production of both will be similar to those of European production [33]. The direct and indirect emissions from applying $\mathrm{N}$ fertiliser are based on the default values given by the IPCC for the emission factor of direct $\mathrm{N}_{2} \mathrm{O}$ emissions from managed soils, of indirect emissions from managed soils through volatisation and leaching or runoff, for the fractions of organic and synthetic $\mathrm{N}$ fertiliser that will volatise as $\mathrm{NH}_{3}$ or $\mathrm{NO}_{x}$, and for the fraction of all $\mathrm{N}$ fertiliser added to the soil that is lost through leaching or runoff [18].

Kernels, produced at a rate of $240 \mathrm{~kg} \mathrm{t}^{-1} \mathrm{CPO}$, are separated into $45 \%$ PKO and 53\% PKE. Table 3 also presents the PKO emission credit, which is based on the average production of petroleum-based surfactants and PKO surfactants in Germany in 1996 [34], and the emission credit for PKE, which is based on average soybean production in the USA, import to and processing in the Netherlands [32].

The amount of $\mathrm{CH}_{4}$ emitted during POME treatment at the mill is based on the case study POME yield of $3 \mathrm{~m}^{3}$ POME per $\mathrm{t} \mathrm{CPO}$, a biogas yield of $28 \mathrm{~m}^{3}$ biogas per $\mathrm{m}^{3}$ POME [22] and a $40 \%$ share of $\mathrm{CH}_{4}$ in the biogas [22].

Typical transportation types, fuels and emissions are taken from Damen and Faaij [35], and distances are applied as found in the case study $(100 \mathrm{~km}$ dedicated truck transport of CPO from the mill to the harbour/refinery, $17000 \mathrm{~km}$ ocean vessel transport to the Netherlands and $200 \mathrm{~km}$ dedicated transport by inland ships to the power plant).

The sensitivity analysis tests those parameters of CPO production for which large ranges were found. The parameters tested and the ranges applied are shown in Table 4.

\subsection{PFAD electricity chain}

Input data for CPO refining are based on the data obtained during the field visit and relate primarily to the energy consumption at the refinery (Table 5). Economic allocation of emissions related to the refinery are based on February 2007 
Table 5 - Parameters and values for PFAD electricity chain and biodiesel chain

\begin{tabular}{|c|c|c|c|}
\hline Parameters & Unit & Value & Source \\
\hline \multicolumn{4}{|l|}{ PFAD electricity chain } \\
\hline PFAD production rate & $\mathrm{kg}$ PFAD $\mathrm{t}^{-1} \mathrm{RBD}$ palm oil & 50 & Case study \\
\hline Energy content PFAD & $\mathrm{MJ} \mathrm{kg}^{-1}$ & 38.5 & {$[50]$} \\
\hline \multicolumn{4}{|l|}{ Energy requirements at Refinery } \\
\hline Diesel & $\mathrm{MJ} \mathrm{t}^{-1} \mathrm{CPO}$ & 200 & Case study \\
\hline Biomass & $\mathrm{MJ} \mathrm{t}{ }^{-1} \mathrm{CPO}$ & 650 & Case study \\
\hline Electricity from grid & $\mathrm{kWh} \mathrm{t}^{-1} \mathrm{CPO}$ & 23.4 & Case study \\
\hline \multicolumn{4}{|l|}{ Biodiesel chain } \\
\hline PME density & $\mathrm{kg} \mathrm{m}^{-3}$ & 880 & [51] \\
\hline Conversion efficiency (CPO-PME) & $\mathrm{kgPME} \mathrm{t}^{-1} \mathrm{CPO}$ & 960 & [38] \\
\hline Energy requirements transesterification & $\mathrm{kWh} \mathrm{m}^{-3} \mathrm{PME}$ & 250 & [29] \\
\hline Methanol emissions & $\mathrm{kgCO}_{2}$-eq $\mathrm{t}^{-1}$ methanol & 786 & {$[33]$} \\
\hline Catalyst $(\mathrm{NaOH})$ & $\mathrm{kgCO}_{2}$-eq $\mathrm{kg}^{-1} \mathrm{NaOH}$ & 1.2 & {$[40]$} \\
\hline Emissions from synthetic glycerine & $\mathrm{kgCO}_{2}$-eq kg ${ }^{-1}$ glycerine & 9.6 & {$[41]$} \\
\hline Emissions from wheat as animal feed & $\mathrm{kgCO}_{2}$-eq $\mathrm{t}^{-1}$ feed & 744 & {$[42]$} \\
\hline Distribution of biodiesel in NL & $\mathrm{gCO}_{2}$-eq $\mathrm{MJ}^{-1} \mathrm{PME}$ & 1.1 & [28] \\
\hline End use of biodiesel & $\mathrm{gCO}_{2}$-eq MJ ${ }^{-1} \mathrm{PME}$ & 5.9 & Own calculations based on [28] \\
\hline
\end{tabular}

\section{Table 6 - Life cycle GHG emissions of the reference fossil energy chains}

\begin{tabular}{|c|c|c|c|}
\hline Parameter & Unit & Value & Source \\
\hline Claus power plant & $\mathrm{gCO}_{2}$-eq kWh ${ }^{-1}$ & 559 & Provision: own calculations based on [41]; Use [52] \\
\hline Dutch average electricity mix (2000) & $\mathrm{gCO}_{2}$-eq kWh ${ }^{-1}$ & 615 & {$[32]$} \\
\hline Modern NG power plant & $\mathrm{gCO}_{2}$-eq kWh ${ }^{-1}$ & 400 & {$[41]$} \\
\hline Dutch coal power plant & $\mathrm{gCO}_{2}$-eq kWh $\mathrm{kW}^{-1}$ & 1000 & [32] \\
\hline EU25 average electricity mix (2000) & $\mathrm{gCO}_{2}$-eq $\mathrm{kWh}^{-1}$ & 486 & {$[41]$} \\
\hline Fossil diesel & $\mathrm{gCO}_{2}$-eq $\mathrm{MJ}^{-1}$ & 88 & Provision [28]; Use [18] \\
\hline
\end{tabular}

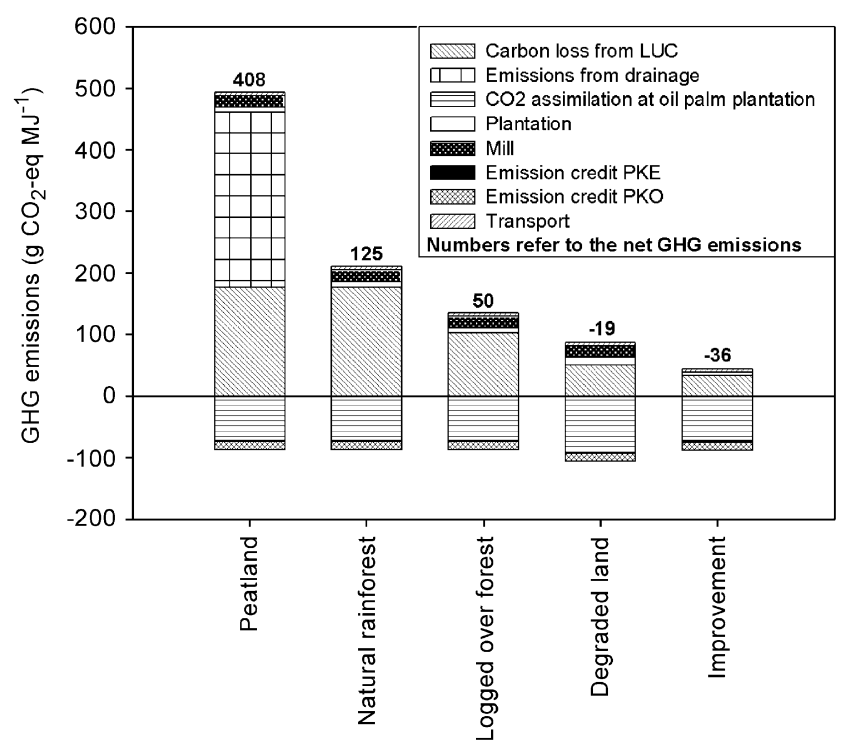

Fig. 3 - GHG emissions of CPO delivered to power plant, by source.

hardly affects the results. The factors that are most uncertain are the emission factors for fertiliser production, i.e. ammonium sulphate and urea production, and the $\mathrm{N}_{2} \mathrm{O}$ emission factor from nitrogen fertiliser application. However, despite this uncertainty, the emission factors of ammonium sulphate and urea production scarcely affect overall emissions. In contrast, the range of the $\mathrm{N}_{2} \mathrm{O}$ emission factor from managed soils as given by the IPCC [18] can cause the overall GHG emissions to increase or decrease by more than $10 \%$.

\subsection{PFAD electricity chain}

The total GHG emissions of PFAD-based electricity production are only one-sixth of the emissions of the CPO base case (Table 7).

\subsection{Biodiesel chain}

The results of the biodiesel GHG emission analysis show that the emissions of CPO used for biodiesel are in most cases lower than when CPO is used for electricity (Table 8). The main reason for this is the additional processing step that, using only a relatively small amount of fossil energy, produces glycerine as a by-product that, if synthetically produced, is very energy intensive and, therefore, receives a high emission credit. When glycerine replaces animal feed instead of synthetic glycerine, GHG emissions of biodiesel nearly double. 


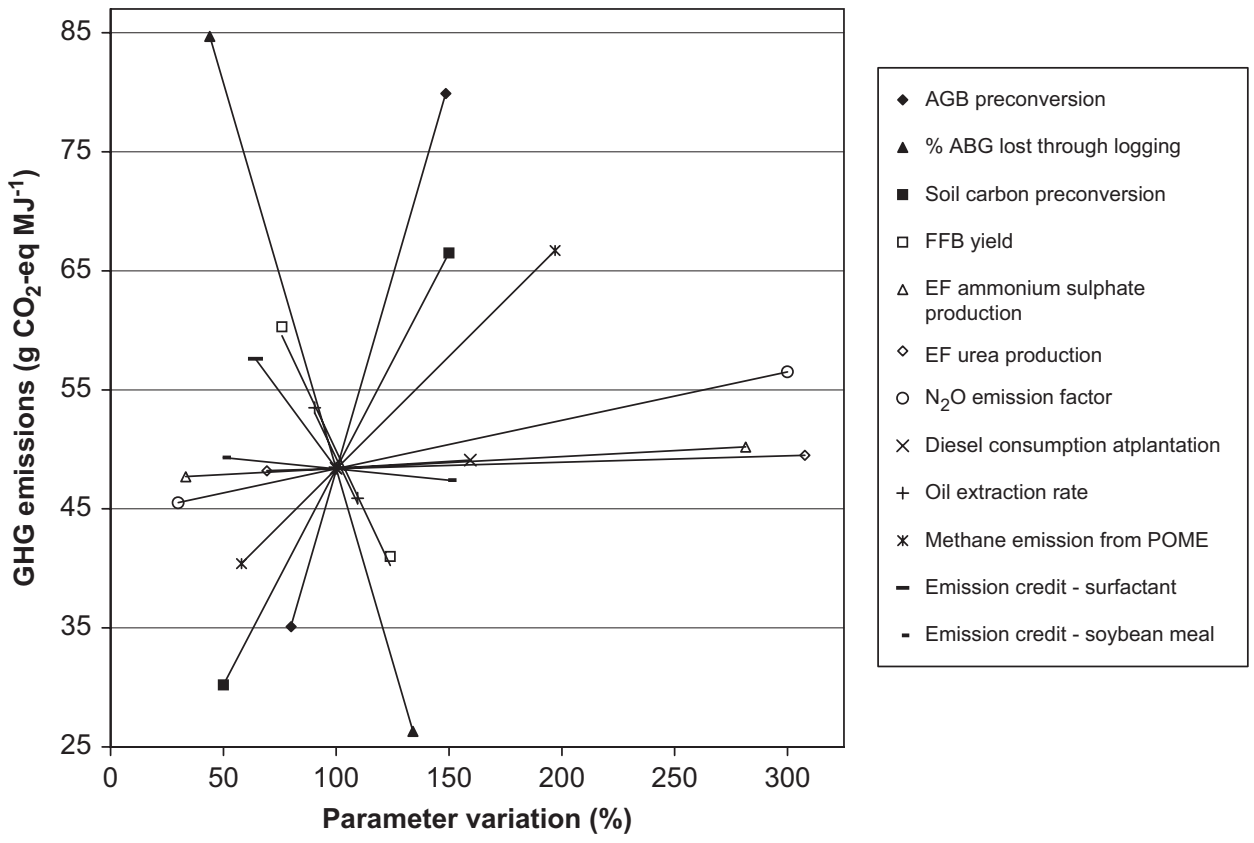

Fig. 4 - Sensitivity of GHG emissions of base case (logged-over forest).

Table 7 - GHG emissions of the PFAD production chain, by component (all values are in $\mathrm{g} \mathrm{CO}_{2}$-eq $\mathrm{MJ}^{-1} \mathrm{PFAD}$ )

\begin{tabular}{lcccc}
\hline & PFAD base case & Mass allocation & Energy allocation & No refinery emissions \\
\hline Refinery & 1.6 & 2.2 & 2.2 & 0 \\
Alternative use & 2.8 & 2.8 & 2.8 & 2.8 \\
Transport & 4.2 & 4.2 & 4.2 & 4.2 \\
Total & 8.6 & 9.2 & 9.2 & 7.0 \\
\hline
\end{tabular}

\section{Table 8 - GHG emissions of the biodiesel chain compared to the CPO electricity chain}

\begin{tabular}{|c|c|c|c|c|c|c|}
\hline & \multicolumn{2}{|c|}{ Emissions ( $\mathrm{gCO}_{2}$-eq $\mathrm{MJ}^{-1} \mathrm{CPO}$ ) } & \multicolumn{2}{|c|}{ Emission reduction (\%) } & \multicolumn{2}{|c|}{ Payback time (years) } \\
\hline & Biodiesel & CPO electricity ${ }^{\mathrm{a}}$ & Biodiesel & CPO electricity ${ }^{\mathrm{a}}$ & Biodiesel & CPO electricity ${ }^{\mathrm{a}}$ \\
\hline Peatland forest & 391 & 407 & -337 & -528 & 169 & 320 \\
\hline Natural rain forest & 107 & 123 & -20 & -90 & 30 & 57 \\
\hline Base case & 32 & 48 & 65 & 25 & 8 & 16 \\
\hline Base case (animal feed) & 61 & $\mathrm{n} / \mathrm{a}$ & 32 & $\mathrm{n} / \mathrm{a}$ & 10 & $\mathrm{n} / \mathrm{a}$ \\
\hline Degraded land & -51 & -35 & 157 & 154 & $\mathrm{n} / \mathrm{a}$ & $\mathrm{n} / \mathrm{a}$ \\
\hline Improvement & -53 & -37 & 159 & 156 & $\mathrm{n} / \mathrm{a}$ & $\mathrm{n} / \mathrm{a}$ \\
\hline
\end{tabular}

\subsection{GHG emission reductions and carbon payback time}

The base case can meet the Cramer Commission's 50\% emission reduction target only if it is compared to coal electricity, while palm oil electricity from degraded land and from CPO production with improved management results in emission reductions of more than $70 \%$, regardless of the fossil reference system it is compared to (Fig. 5). The GHG emission reductions of CPO electricity from land that was previously natural rainforest or peatland are negative, indicating that the use of CPO from these cases results in more emissions than the fossil reference systems. In contrast, PFAD-based electricity has a large potential for reducing GHG emissions (Fig. 5).

Palm-oil-based biodiesel can result in GHG emission savings above $60 \%$ if glycerine replaces synthetic glycerine and if the palm oil is not from converted natural rainforest or peatland (Table 8). Emissions reductions from biodiesel are significantly higher than from CPO in power production due to the emission credit given to the biodiesel by-product glycerine and due to the relatively low electric efficiency of the Claus Power Plant. If glycerine is used to displace animal 


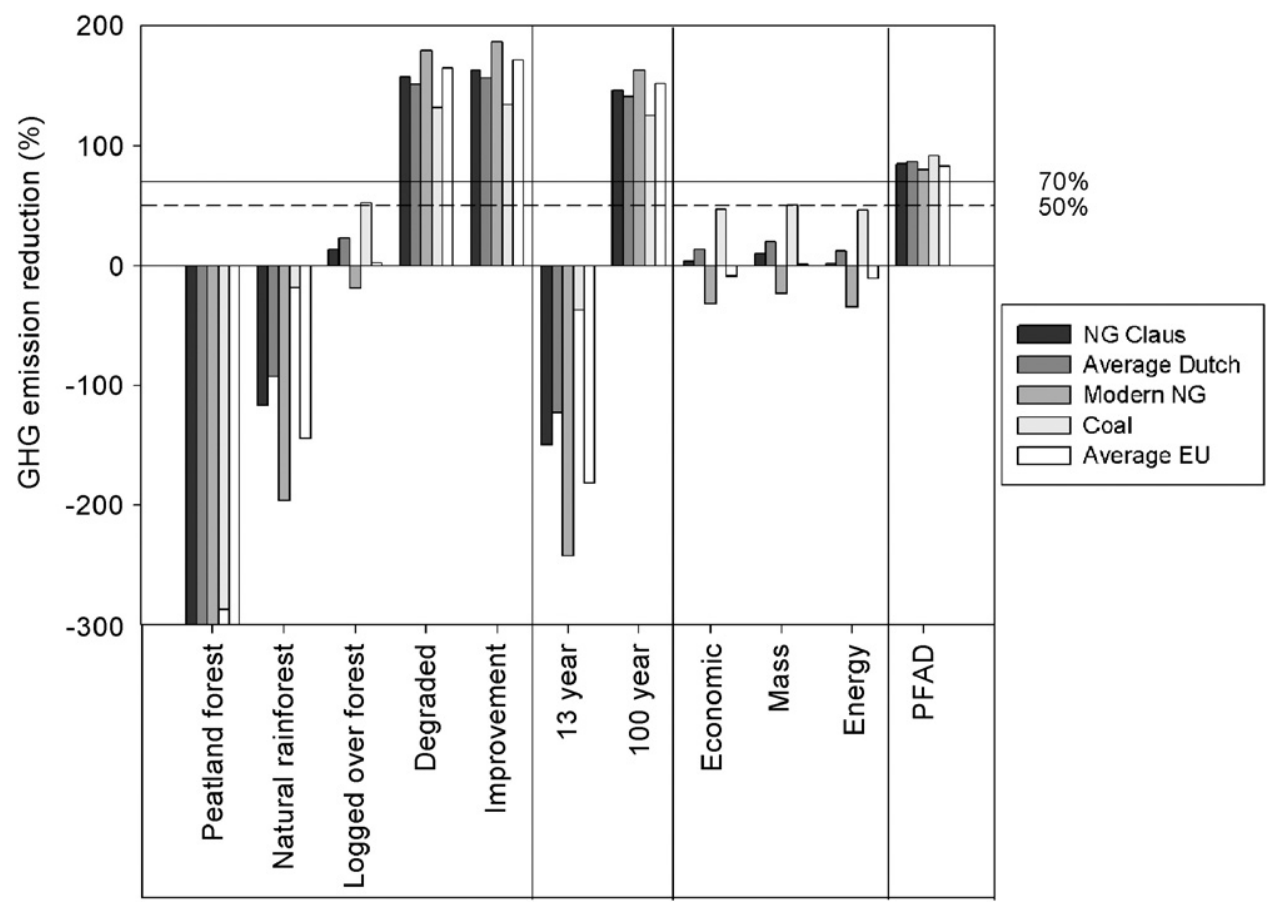

Fig. 5 - GHG emission reductions of various CPO and PFAD electricity production chains compared to different fossil reference systems.

feed rather than synthetic glycerine, the emission reduction drops to $32 \%$, which is still slightly higher than the bioelectricity base case.

The carbon payback time is determined for those CPO electricity and biodiesel chains with reference land use cases in which a net carbon loss from LUC towards oil palm plantations is observed. High carbon payback periods for peatland and natural rainforest confirm that palm oil from these land types cannot be considered sustainable. In contrast, the base case on logged-over forest could contribute to GHG emission savings after eight (biodiesel) to 16 years (electricity) of palm oil production (Table 8).

\subsubsection{Methodological issues}

The effects of three methodological issues on the GHG balance are presented next for the CPO electricity chain: the allocation period for LUC emissions, the method of allocating emissions to the different products and the choice of fossil electricity reference system. These issues are expected to have a similar effect on the two other chains and are therefore not further elaborated here.

The allocation period for LUC emissions has a large impact on whether GHG emission reduction targets may be achieved (Fig. 5). A shorter allocation period of 13 years results in negative GHG emission reductions in the base case. This was also found to be true for the other LUC cases, except when degraded land is planted with palm oil. An allocation period of 100 years results in emission reductions of more than $100 \%$ in the base case and at least $70 \%$ in other LUC cases. An exception is the peatland case, which has a negative emission reduction even with an allocation period of 100 years.

In contrast, neither the method for allocating emissions from by-products nor the choice of a fossil electricity reference system has a significant effect on the GHG emission reduction. Fig. 5 illustrates that, although different fossil electricity reference systems do cause some variation in the bioelectricity chains' overall emission reductions, the variation is generally not sufficient to affect whether the $50-70 \%$ emission reduction target is reached. Only when a case is already borderline does the fossil reference system affect whether the reduction target is met.

\section{Discussion}

GHG emissions from LUC were calculated according to the Tier 1 methodology of the IPCC guidelines for national GHG inventories, which assumes that LUC does not cause a carbon stock change in belowground biomass [18]. However, large amounts of carbon may actually be stored in belowground biomass. While not enough data was available to have included this aspect in the main analysis of this study, it is possible to compare the carbon in belowground biomass of natural rainforest to that of grassland and oil palm plantation (based on IPCC default values for belowground biomass to AGB for natural rainforest and tropical grassland [18] and on data from the field experiments of Syahrinudin [30]). The comparison reveals that carbon in belowground biomass is $41 \mathrm{tC} \mathrm{ha}^{-1}$ for natural rainforest, $5 \mathrm{tCha}^{-1}$ for grassland and $19 \mathrm{tCha}^{-1}$ for oil palm plantation, indicating that the assumption that LUC does not cause a carbon stock change in belowground biomass is not valid. However, the inclusion of carbon in belowground biomass would not alter the general outcome of this analysis but would amplify the result that CPO production on degraded land can act as a carbon sink and that converting natural rainforest to oil palm plantations results in higher GHG emissions than a fossil-based system. 
Other important aspects of the LUC issue are the displacement of prior crop production and the possible LUC induced by the movement of prior crop production to other areas or the replacement of prior crop products by alternative resources. Reinhardt et al. [43] have shown that replacement of prior crop products, such as converting a coconut plantation to an oil palm plantation and substituting coconut oil with fossil oil surfactant and coconut press cake for fodder with soybean meal, causes GHG emissions that are even larger than when palm oil is produced on land that used to be natural rainforest. In such cases, Cramer Commission GHG emission targets could not possibly be met. Although the Cramer Commission has thus far excluded GHG emissions from indirect LUC from the movement of prior crop production, its sub-commission on the GHG calculation tool advises the immediate initiation of a macro-level monitoring scheme in order to investigate the effects of production displacement on the GHG balance [16]. Searchinger et al. [20] recently emphasised the need for including indirect LUC in the GHG balance calculations, concluding that a focus on direct LUC would produce positive results for many chains that, when implemented, would lead to less or possibly no GHG emission reductions in reality.

The feasibility of the suggested management improvement options should also be addressed. Of the four suggested improvement options, the increased yield option is economically most interesting because of the increased income it implies. The application of more organic fertiliser is already becoming more common in Malaysia due to a new law that prohibits the direct discharge of treated POME into waterways, causing more of the nutrient-rich slurry to be spread on the plantation. However, the most effective option for reducing GHG emissions, planting oil palm on degraded land, is rare due to the fact that degraded land does not provide initial capital from timber extraction (as does natural rainforest), entails higher establishment costs and possibly reduced yields. The fourth improvement option, which is the second most beneficial option for GHG emission reduction, relates to the collection of $\mathrm{CH}_{4}$ from POME treatment. Currently, this option is not commonly found in the Malaysian palm oil industry, but interest in POME biogas collection and electricity production has been rising rapidly because of the possibility of getting certified emission reductions through CDM projects [22]. In addition to these improvement options, other options for reducing GHG emissions should be identified and further studied.

PFAD-based electricity was found to have very low emissions compared to both fossil reference systems and to CPObased electricity production. The most important reason for this outcome is that PFAD is treated as a by-product so only those emissions that are generated in direct connection with PFAD processing, transport and use are accounted for. Based on the mass balance of a refinery, it makes sense to treat PFAD as a by-product. However, this choice may be debatable given that PFAD is a valuable product for the oleochemical and animal feed industries. In addition, by only including emissions from the refinery process onward, PFAD-based electricity from unsustainably produced CPO could be considered sustainable. Resolving this inconsistency requires a general discussion about when to consider a product a byproduct only and, in this case specifically, how to account for the possibility that unsustainable CPO may be used for PFAD production.

Based on the results of the GHG emission analysis of the electricity chains, a simple decision tree was made for determining the level of GHG emission reductions that can be reached under different conditions (Fig. 6). This decision tree is simplified and actual compliance with GHG emission criteria depends on local conditions.

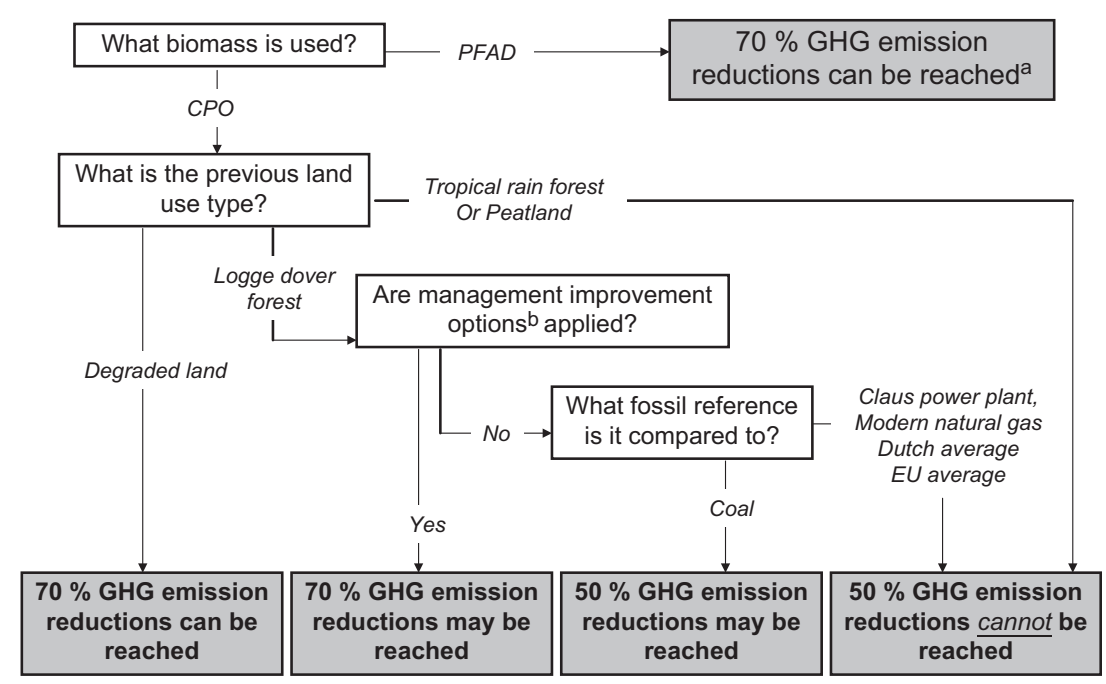

Fig. 6 - A simple decision tree for determining what emission reductions can be achieved from palm-oil-based electricity production. a Assuming that PFAD is treated as a by-product. ${ }^{b}$ The improvement options refer to (1) establishing a new plantation on degraded land, (2) increasing FFB yields, (3) treating POME in closed conditions and collecting and burning $\mathrm{CH}_{4}$ for electricity production and (4) applying slurry from POME treatment to the plantation as organic fertiliser. 


\section{Conclusions}

This study found that palm oil energy chains based on former natural rainforest or peatland have such large emissions that they cannot meet the 50-70\% GHG emission reduction target set by the Cramer Commission. The case study, palm oil production on logged-over forest, can only meet the emission reduction target of $50 \%$ if compared to coal-based electricity production. However, if CPO production takes place on degraded land, the management of the production of CPO is improved (including the use of degraded land for palm oil production), or if the by-product PFAD is used for electricity production, the criteria can be met, and palm-oil-based electricity can be considered sustainable from a GHG emission point of view. Even though the biodiesel base case on logged-over forest can meet the Cramer Commission's emission reduction target for biofuels of $30 \%$, other cases, i.e. oil palm plantations on degraded land and improved management, can achieve emissions reductions of $150 \%$ or more and can turn oil palm plantations into carbon sinks.

This study demonstrates that LUC is the most decisive factor in overall GHG emissions and thus may not be neglected in GHG emission calculations of palm-oil-based energy or any other type of bioenergy. Related to LUC emissions is the issue of how to deal with PFAD-based electricity that is considered sustainable with respect to GHG emissions but that originates from unsustainably produced CPO. This issue requires more detailed discussion as it is also relevant for all other residues used for bioenergy. Another important factor in overall GHG emissions from palm-oil-based energy production is the allocation period for LUC emissions. A variation in the allocation period from the 25 years in the base case to 13 years results in negative GHG emission reduction percentages in all cases except the degraded land and the improved management cases. Conversely, an extension of the allocation period to 100 years leads to all but one case (peatland) meeting the Cramer Commission targets. As a result, even the natural rainforest case would be considered sustainable from a GHG emission point of view. The fact that the results can be significantly altered by varying the length of the allocation period for LUC emissions means that an appropriate time period must be selected when evaluating the GHG emission reduction potential of bioenergy.

Given these considerations, the study concludes that in order for bioelectricity and biodiesel to be sustainably produced from palm oil and its derivatives, only degraded land should be used for palm oil production and plantation management should be improved.

\section{Acknowledgements}

The authors would like to thank Ariane Kaper (Utrecht University) for her help on the land use issue, David Ogg and Johan Maris (Control Union) for organising the field visit, the managers of the visited plantations for their enthusiasm about our work, their patience in providing data and their hospitality, and Prof. Wim Turkenburg (Utrecht University) and Ralph Overend for critically reading the manuscript.

R E F E R E N C E S

[1] Colchester M, Jiwan N, Andiko, Sirait M, Firdaus AY, Surambo A, et al. Promised land-palm oil and land acquisition in Indonesia: implications for local communities and indigenous peoples. Moreton-in-Marsh, UK: Forest Peoples Programme, Perkumpulan Sawit Watch, HuMA and the World Agroforestry Centre; 2006. Retrieved July 3, 2007 from <http:// www.forestpeoples.org/documents/prv_sector/oil_palm/ promised_land_eng.pdf $>$.

[2] Wakker E. Greasy palms: the social and ecological impacts of large-scale oil palm plantation development in Southeast Asia. London, UK: Friends of the Earth; 2004. Retrieved February 08, 2007 from 〈http://www.foe.co.uk/resource/ reports/greasy_palms_impacts.pdf $\rangle$.

[3] Helms H, Reinhardt GA, Rettenmaier N. Bioenergie aus Palmöl: Ökologische Chancen und Risiken. Energiewirtschaftliche Tagesfragen 2006;56(11):70-3.

[4] CREM, Both ENDS, COS, and Natuur en Milieu. Dutch import of biomass: producing countries' point of view on the sustainability of biomass exports. CREM Report number 06.885, Amsterdam, the Netherlands, 2006. Retrieved August 3, 2007 from 〈http://www.bothends.org/strategic/070502 report\%20sustainability\%20of\%20imported\%20biomass.pdf $\rangle$.

[5] Ryckmans Y, Marchal D, André N. Energy balance and greenhouse gas emissions of the whole supply chain for the import of wood pellets to power plants in Belgium. In: ETA-Florence, WIP-Munich, editors, 15th European biomass conference and exhibition, May 7-11, 2007, Berlin, Germany.

[6] van Dam J, Junginger M, Faaij APC, Juergens I, Best G, Fritsche U. Overview of recent developments in sustainable biomass certification. 2006: IEA Bioenergy Task 40. Retrieved February 19, 2008 from 〈http://www.globalbioenergy.org/uploads/ media/0612_IEA_TASK_40_-_Overview_of_recent_ developments_in_sustainable_biomass_certification_-draft_for_comments_01.pdf $>$.

[7] Department for Transport. Carbon and sustainability reporting within the renewable transport fuel obligation. requirements and guidance. Draft Government Recommendation to RTFO Administrator, Cleaner Fuels and Vehicles, Department for Transport, UK Government, 2007. Retrieved February 18, 2008 from 〈http://www.dft.gov.uk/pgr/roads/environment/rtfo/ $\rangle$.

[8] Cramer Commission. Testing framework for sustainable biomass. Final report from the project group "Sustainable production of biomass” 2007: Energy Transition's Interdepartmental Programme Management (IPM), the Netherlands. Retrieved April 18, 2007 from 〈http://www.senternovem.nl/ mmfiles/Testing\%20framework\%20for\%20sustainable\%20 biomass_tcm24-232796.pdf $>$.

[9] European Commission. Biofuel issues in the new legislation on the promotion of renewable energy. Public consultation exercise, April-May 2007. Energy and Transport DirectorateGeneral, European Commission, April 2007. Retrieved June 19, 2007 from <http://ec.europa.eu/energy/res/consultation/ doc/2007_06_04_biofuels/2007_06_04_public_consultation_ biofuels_en.pdf $>$.

[10] van Dam J, Faaij APC, Daugherty E, Gustavvson L, Elsayed MA, Horne RE, et al. Approach for development of standard tool for evaluating greenhouse gas balances and costeffectiveness of biomass energy technologies. 2004: IEA Bioenergy Task 38. Retrieved June 15, 2007 from 〈http:// www.ieabioenergy-task38.org/publications/Biomitre_Tool_ Development.pdf $>$. 
[11] Dornburg V, Faaij APC. Cost and $\mathrm{CO}_{2}$-emission reduction of biomass cascading: methodological aspects and case study of SRF poplar. Climatic Change 2005;71(3):373-408.

[12] Fargione J, Hill J, Tilman D, Polasky S, Hawthorne P. Land clearing and the biofuel carbon debt. Science 2008;319(5867):1235-8.

[13] Germer J, Sauerborn J. Estimation of the impact of oil palm plantation establishment on greenhouse gas balance. Environmental Development and Sustainability 2007, in press, doi:10.1007/s10668-006-9080-1.

[14] Reijnders L, Huijbregts MAJ. Palm oil and the emission of carbon-based greenhouse gases. Journal of Cleaner Production 2008;16(4):477-82.

[15] Bauen A, Watson P, Howes J. Carbon reporting within the renewable transport fuel obligation-methodology. London, UK: E4tech; 2006. Retrieved February 18, 2008 from <http:// www.dft.gov.uk/consultations/closed/rtforeporting/ carbonreporting $>$.

[16] Bergsma G, Vroonhof J, Dornburg V. The greenhouse gas calculation methodology for biomass-based electricity, heat and fuels-the view of the Cramer Commission. Project group "Sustainable Production of Biomass," Report from the working group $\mathrm{CO}_{2}$ Methodology, 2006. Retrieved May 25, 2007 from 〈http://www.senternovem.nl/mmfiles/The greenhouse_gas_calculation_methodology_for_biomassbased_electricity_heat_and_fuels_tcm24-221151.pdf $>$.

[17] Wicke B, Dornburg V, Faaij APC, Junginger M. A greenhouse gas balance of electricity production from co-firing palm oil products from Malaysia. NWS-E-2007-33, Department of Science, Technology and Society, Utrecht University, Utrecht, the Netherlands, 2007. Retrieved May 25, 2007 from <http:// www.chem.uu.nl/nws/www/publica/Publicaties2007/ NWS-E-2007-33.pdf $>$

[18] IPCC. 2006 IPCC guidelines for national greenhouse gas inventories. Hayama, Japan: Institute for Global Environmental Strategies; 2006 Retrieved January 18, 2007 from 〈http://www.ipcc-nggip.iges.or.jp//public/2006gl/index.htm 〉.

[19] Dehue B, Hamelinck C, de Lint S, Archer R, Garcia E, van den Heuvel E. Sustainability reporting within RTFO: framework report, 2007, Ecofys, Utrecht, the Netherlands. Commissioned by UK Department for Transport. Retrieved February 28, 2008 from 〈http://www.dft.gov.uk/consultations/closed/ rtforeporting/sustainabilityreportingv2 $\rangle$.

[20] Searchinger T, Heimlich R, Houghton RA, Dong F, Elobeid A A, Fabiosa J, et al. Use of US croplands for biofuels increases greenhouse gases through emissions from land-use change. Science 2008;319(5867):1238-40.

[21] Stalmans M, Berenbold H, Berna JL, Cavalli L, Dillarstone A, Franke M, et al. European life-cycle inventory for detergent surfactants production. Tenside Surfactants Detergents 1995;32(2):84-109.

[22] Shirai Y, Wakisaka M, Yacob S, Hassan MA, Suzuki S. Reduction of methane released from palm oil mill lagoon in Malaysia and its countermeasures. Mitigation and Adaptation Strategies for Global Climate Change 2003;8(3):237-52.

[23] Rupilius W, Ahmad S. The changing world of oleochemicals. Palm Oil Developments 2006;44:15-28.

[24] Bradley D. European market study for BioOil (Pyrolysis Oil). Ottawa, Ontario, Canada: Climate Change Solutions; 2006. Retrieved March 15, 2007 from 〈http://www.bioenergytrade. org/downloads/bradleyeuropeanbiooilmarketstudyfinaldec15. pdf $>$.

[25] Postlethwaite D. A life-cycle inventory for the production of soap in Europe. Tenside Surfactants Detergents 1995;32(2):157-70.

[26] Meher LC, Vidya Sagar D, Naik SN. Technical aspects of biodiesel production by transesterification-a review. Renewable \& Sustainable Energy Reviews 2004;10(3):248-68.
[27] Bernesson S, Nilsson D, Hansson P-A. A limited LCA comparing large- and small-scale production of rape methyl ester (RME) under Swedish conditions. Biomass and Bioenergy 2003;26(6):545-59.

[28] EUCAR, CONCAWE, and JRC/IES. Well-to-wheels analysis of future automotive fuels and powertrains in the European context-WELL-to-TANK Report, TANK-to-WHEEL Report, WELL-to-WHEELS Report, Version 2c, March 2007. Retrieved June 5, 2007 from 〈http://ies.jrc.cec.eu.int/wtw.html $\rangle$.

[29] Smeets E, Junginger M, Faaij APC. Supportive study for the OECD on alternative developments in biofuel production across the world. NWS-E-2005-141. Utrecht, the Netherlands: Department of Science, Technology and Society, Utrecht University; 2005. Retrieved June 12, 2007 from 〈http:// www.chem.uu.nl/nws/www/publica/Publicaties2005/ E2005-141.pdf $>$.

[30] Syahrinudin. In: Vlek PLG, Denich M, Martius C, Rodgers C, van de Giesen N, editors. The potential of oil palm and forest plantations for carbon sequestration on degraded land in Indonesia. Ecology and development series no. 28. Göttingen, Germany: Cuvillier Verlag; 2005.

[31] Tangsathitkulchai C, Sittichaitaweekul Y, Tangsathikulchai $M$. Temperature effect on the viscosities of palm oil and coconut oil blended with diesel oil. Journal of the American Oil Chemists Society 2004;81(4):401-5.

[32] Damen K, Faaij A. A greenhouse gas balance of two existing international biomass import chains. Mitigation and Adaptation Strategies for Global Change 2006;11(5):1023-50.

[33] Ecoinvent. Ecoinvent database Data V1.3. 2004, Swiss Centre for Life Cycle Inventories 〈http://www.ecoinvent.ch/ $\rangle$.

[34] Patel M. Closing carbon cycles: Carbon use for materials in the context of resource efficiency and climate change. Ph.D. dissertation, Utrecht University, Utrecht, the Netherlands, 1999.

[35] Damen K, Faaij A. A life cycle inventory of existing biomass import chains for "green" electricity production. NW\&SE-2003-01. Utrecht, the Netherlands: Department of Science, Technology and Society, Copernicus Institute for Sustainable Development, Utrecht University; 2003. Retrieved January 12, 2007 from 〈http://www.ieabioenergy-task38.org/projects/ task38casestudies/nl-fullreport.pdf $\rangle$.

[36] MPOB. Economics and industry development divisionstatistics. Malaysian Palm Oil Board, 2006. Retrieved 22.03.2007 from 〈http://econ.mpob.gov.my/economy/EID_web.htm $\rangle$.

[37] Nemecek T, Heil A, Huguenin O, Meier S, Erzinger S, Blaser S, et al. Life cycle inventories of agricultural production systems: Data v1.1 (2004). Ecoinvent report no. 15. Duebendorf, Switzerland: Ecoinvent Centre; 2004.

[38] Choo YM, Ma AN, Cheag KY, Rusnani AM, Andrew YKC, Harrison LLN, et al. Palm diesel: green and renewable fuel from palm oil. Palm Oil Developments 2005(42):3-7.

[39] Borken J, Patyk A, Reinhardt G. Basisdaten für ökologische Bilanzierungen-Einsatz von Nutzfahrzeugen in Gütertransport. Wiesbaden, Germany: Landwirtscahft und Bergbau, Vieweg; 1999.

[40] PRé Consultants. BUWAL 250 Database V2, 2004 〈http:// www.pre.nl/ $>$.

[41] Umweltbundesamt. Prozessorientierte Basisdaten fuer Umweltmanagement-Instrumente. Ministry of the Environment, Germany, 2006. Retrieved March 27, 2007 from 〈http:// www.probas.umweltbundesamt.de/php/index.php $\rangle$.

[42] Nielsen PH, Nielsen AM, Weidema BP, Dalgaard R, Halberg N. LCA Food Database, 2003 〈http://www.lcafood.dk/ >.

[43] Reinhardt G, Rettenmaier N, Gaertner S, Pastowski A. Rain forest for biodiesel? Ecological effects of using palm oil as a source of energy. Frankfurt, Germany: WWF; 2007. Retrieved May 21, 2007 from 〈http://www.wwf.de/fileadmin/fm-wwf/ pdf_neu/wwf_palmoil_study_english.pdf $\rangle$. 
[44] Lasco RD. Forest carbon budgets in Southeast Asia following harvesting and land cover change. Science in China Series C 2002;45:55-64.

[45] Rieley JO, Page SE, editors. Wise use of tropical Peatlands: focus on Southeast Asia. Wageningen, the Netherlands: Alterra; 2005.

[46] Wood S, Cowie A. A review of greenhouse gas emission factors for fertilizer production. IEA Bioenergy Task 38, 2004. Retrieved March 22, 2007 from 〈http://www.ieabioenergytask38.org/publications/GHG_Emission_Fertilizer\% 20Production_July2004.pdf $>$.

[47] Tang TS, Teoh PK. Palm kernel oil extraction-the Malaysian experience. Journal of the American Oil Chemists Society 1985;62(2):254-8.

[48] Schmidt JH. Life cycle assessment (LCA) of rapeseed oil and palm oil. Ph.D. dissertation, Aalborg University, Aalborg, Denmark, 2007. Retrieved September 17, 2007 from 〈http:// www.plan.aau.dk/ jannick/research.htm $>$.
[49] Chavalparit O. Clean technology for the crude palm oil industry in Thailand. Ph.D. dissertation, Wageningen University, Wageningen, the Netherlands, 2006. Retrieved January 26, 2007 from 〈http://library.wur.nl/wda/dissertations/ dis4003.pdf $>$.

[50] Erbrink JJ. Marktoverzicht bio-olien voor energie toepassing. Arnhem, the Netherlands: Kema; 2004 Retrieved March 9, 2007 from <http://www.tuinbouw.nl/website/ptcontent.nsf/ vwAllOnID/E51A66727A11B34EC1256EBC004B0F51/\$File/ 04-7051.marktrap.PT-LNV.pdf $>$.

[51] Vanichseni T, Intaravichai S, Saitthiti B, Kiatiwat T. Potential biodiesel production from palm oil for Thailand. Kasetsart Journal, Natural Sciences 2002;36(1):83-97.

[52] Essent. Personal and written communication with Paul Romijn, Geert Ardon and Peter-Paul Schouwerberg on power production at Claus Power Plant, Maasbracht, the Netherlands, January-March 2007. 